\title{
The TOL Plasmid is Naturally Derepressed for Transfer
}

\author{
By DAVID E. BRADLEY ${ }^{1 *}$ AND PETER A. WILLIAMS ${ }^{2}$ \\ ${ }^{1}$ Faculty of Medicine, Memorial University of Newfoundland, St John's, Newfoundland, \\ Canada AIB 3 V6 \\ ${ }^{2}$ Department of Biochemistry and Soil Science, University College of North Wales, Bangor, \\ Gwynedd LL57 2UW, Wales, U.K.
}

(Received 9 March 1982; revised 20 May 1982)

\begin{abstract}
Pseudomonas putida mt-2, formerly known as Pseudomonas arvilla $\mathrm{mt}-2$, which carries the wildtype TOL plasmid, and $P$. putida strain AC 37 carrying TOL, were completely lysed by the pilusadsorbing plasmid-specific bacteriophages PR4 and PRD1. Pseudomonas putida strain PpS388, also harbouring the plasmid, was not lysed. In a $P$. putida $\mathrm{mt}-2$ host, TOL transferred 18 -fold better on a surface $\left(2.5 \times 10^{-1}\right.$ transconjugants per donor $\left.\mathrm{h}^{-1}\right)$ than in liquid; when P.putida PpS388 was the host, however, a frequency of only $2.3 \times 10^{-4}$ transconjugants per donor $\mathrm{h}^{-1}$ was obtained. Thus, TOL was derepressed for transfer in $P$. putida $\mathrm{mt}-2$ and $P$. putida AC 37 , but not in $P$. putida PpS388. Electron microscopy revealed that TOL determined thick $(8 \cdot 5-10 \mathrm{~nm}$ diameter) flexible pili in large numbers, suggesting constitutive expression in its derepressed state.
\end{abstract}

\section{INTRODUCTION}

TOL is the best studied of the transmissible degradative Pseudomonas plasmids, and belongs to incompatibility group P-9 (Nakazawa \& Yokota, 1973; Williams \& Murray, 1974; Wong \& Dunn, 1974; White \& Dunn, 1978). It can be transferred to Escherichia coli (Benson \& Shapiro, 1978) where it does not express the Tol ${ }^{+}$phenotype. Sensitivity to the conjugative pilus-specific bacteriophage PR4 (Stanisich, 1974; Bradley \& Rutherford, 1975; Bradley, 1979) is specified by TOL to a limited extent in Pseudomonas aeruginosa strains, but apparently not in Pseudomonas putida (White \& Dunn, 1978). The state of repression of the conjugation system of the plasmid has not been defined, but a preliminary electron microscopic study of TOL conjugative pili revealed two kinds of filament in small numbers, suggesting repression (Bradley, $1980 \mathrm{a}$; Bradley, 1981). One resembled a rigid type of conjugative pilus (Bradley, 1980a), while it was thought that the other, which was flexible, was a metabolic product. We report here that wildtype TOL is naturally derepressed for transfer in its original host, Pseudomonas putida mt-2 (formerly Pseudomonas arvilla $\mathrm{mt}-2$ ), that it determines thick flexible conjugative pili constitutively, and that it transfers more efficiently on an agar surface compared with when in a liquid environment.

\section{METHODS}

Bacterial strains, plasmids and bacteriophages. Bacterial strains are listed in Table 1. Strain PaW1 is the original wild-type $P$. putida mt-2 (ATCC 33015) that harbours pWW0, the original TOL plasmid (Williams \& Murray, 1974); the strain is designated PaWl(TOL) for this work. PaW340 was supplied by Dr E. A. Barnsley who obtained it from Dr C. J. Duggleby. Strain PaW340.3 is a non-motile (Fla ${ }^{-}$) mutant of strain PaW340 constructed by conventional mutagenesis with $N$-methyl- $N^{\prime}$-nitro- $N$-nitrosoguanidine (Sigma). This mutant did not spread on a nutrient agar plate covered with a layer of soft nutrient agar $[0.33 \%(\mathrm{w} / \mathrm{v})$ agar $]$, whereas motile strains spread over 1-2 cm. The plasmid pWW0-226 was constructed by the insertion into TOL ( $=\mathrm{pWW} 0$ ) of transposon Tn40I (see Benson \& Shapiro, 1978), followed by benzoate curing (Williams \& Murray, 1974), which results in the loss of the specific $39 \mathrm{~kb}$ region containing the catabolic genes (Downing et al., 1979) but the retention of the $\mathrm{Tn} 401$ element; self-transmissibility is retained. PpS1094(TOL: :Tn40I) was supplied and described by Benson \& Shapiro (1978), and P. putida PpS388 (plasmid-free) by Dr M. Fennewald (Fennewald et al., 1978). Dr G. Jacoby 
provided $P$. putida AC37(TOL), the AC 37 background being derived from strain PpG1 of the Gunsalus collection (Rheinwald et al., 1973). The bacteriophages used were PR4 (Stanisich, 1974; Bradley \& Rutherford, 1975) and PRD1 (Olsen et al., 1974).

Media, culture methods and matings. Oxoid tryptone soya broth was used routinely, with $2 \%(\mathrm{w} / \mathrm{v})$ agar added for plates. M9 minimal salts medium with $2 \%(\mathrm{w} / \mathrm{v})$ agar, $5 \mathrm{mM}-m$-toluate, and an appropriate amino acid supplement $\left(20 \mu \mathrm{g} \mathrm{m}^{-1}\right)$, was used to test or select for the $\mathrm{Tol}^{+}$phenotype. All incubations were at $30^{\circ} \mathrm{C}$. Sensitivity to bacteriophages was assessed by the standard spot and cross-streak methods. Comparative surface and liquid matings were done by the method of Bradley et al. (1980). Transconjugant-selecting plates contained $m$-toluate medium or nutrient agar with carbenicillin $\left(2 \mathrm{mg} \mathrm{ml}^{-1}\right)$ for plasmid selection, and nalidixic acid $\left(200 \mu \mathrm{g} \mathrm{ml}^{-1}\right) \mathrm{or}$ streptomycin $\left(800 \mu \mathrm{g} \mathrm{ml}^{-1}\right)$ for counterselection against donors. Construction of strains by plasmid transfer was by the cross-streak method of Barth (1979) using rifampicin $\left(100 \mu \mathrm{g} \mathrm{ml}^{-1}\right)$ for counterselection.

Electron microscopy. Electron microscopy of Pseudomonas conjugative pili is hampered by the bacteria producing large amounts of extraneous filamentous material and numerous flagella; this applies particularly to $P$. putida. This was largely overcome by constructing strain PaW 340.3 (Fla ${ }^{-}$) described above. The temporary derepression growth method (Bradley, 1980 b), together with a modification for derepressed plasmids, enhanced pilus production. The modified method consisted of mixing a loopful of a $4 \mathrm{~h}$ plate culture of strain $\mathrm{PaW} 340.3$ (TOL) with about half the amount of strain PaW340.3 resistant to rifampicin, on a nutrient plate in a drop of broth. After spreading, drying, and mating for $1 \mathrm{~h}$, as many bacteria as possible were resuspended in a drop of broth on a nutrient plate containing rifampicin $\left(100 \mu \mathrm{g} \mathrm{ml}^{-1}\right)$, spread, and incubated overnight. The confluent bacterial growth was mounted by the method of Bradley $(1980 \mathrm{~b})$, or by centrifugation to reduce the number of cells on the grid. For the latter, $0.1 \mathrm{ml}$ of $0.1 \mathrm{~m}$-ammonium acetate solution was placed in the bottom of a conical centrifuge tube (bottom diameter $5 \mathrm{~mm}$ ) and a large loopful of cells was suspended in it. After mixing briefly, using a rotary mixer, the tube was centrifuged at about $1000 \mathrm{~g}$ for $2.5 \mathrm{~min}$. Most of the bacteria were sedimented without the pili. A carbon-coated grid was then touched on to the surface, washed, and negatively stained. To demonstrate phage PR4 adsorption, the supernatant from the centrifugation was mixed with an equal volume of PR4 suspension (titre $10^{10}$ p.f.u. $\mathrm{ml}^{-1}$ ) in broth, incubated for $1 \mathrm{~h}$, then negatively stained. Alternatively, the ammonium acetate solution in the centrifuge tube was replaced with PR4 suspension. After centrifugation and incubation for adsorption, a grid was touched on the surface and negatively stained.

\section{RESULTS}

\section{Lytic activity of bacteriophages}

Spot test results for phages PR4 and PRD1 are given in Table 1. Complete lysis was obtained with PR4 and susceptible strains, but PRD1 gave slightly less clearing. Lysis of bacterial strains by plasmid-specific phages can only occur if the plasmid specifying sensitivity determines

Table 1. Lysis of Pseudomonas strains by plasmid-specific bacteriophages PR4 and PRD1

\begin{tabular}{|c|c|c|c|c|c|c|}
\hline \multirow[b]{2}{*}{ Bacterial species } & \multirow[b]{2}{*}{ Strain } & \multirow[b]{2}{*}{ Plasmid } & \multirow[b]{2}{*}{ Phenotype* } & \multicolumn{2}{|c|}{ Lysis by phages $†$} & \multirow{2}{*}{$\begin{array}{c}\text { Pilus } \\
\text { synthesis }\end{array}$} \\
\hline & & & & PR4 & PRD1 & \\
\hline P. putida (arvilla) & PaWl & TOL wild-type & $\mathrm{Tol}^{+} \mathrm{Fla}^{+}$ & + & + & Constitutive \\
\hline P. putida (arvilla) & PaW 340 & None & $\mathrm{Tol}^{-} \mathrm{Trp}^{-} \operatorname{Str}^{\mathrm{r}} \mathrm{Fla}^{+}$ & - & - & None \\
\hline P. putida (arvilla) & PaW 340.3 & None & $\mathrm{Tol}^{-}$Trp ${ }^{-} \mathrm{Str}^{r} \mathrm{Fla}^{-}$ & - & - & None \\
\hline P. putida (arvilla) & PaW 340.3 & TOL wild-type & $\mathrm{Tol}^{+} \mathrm{Trp}^{-} \mathrm{Str}^{r} \mathrm{Fla}^{-}$ & + & + & Constitutive \\
\hline P. putida (arvilla) & PaW226 & pWW0-226§ & $\mathrm{Tol}^{-} \mathrm{Cb}^{\mathrm{T}} \mathrm{Fla}^{+}$ & + & + & Constitutive \\
\hline P. putida & PpS1094 & TOL : :Tn401§ & $\mathrm{Tol}^{+} \mathrm{Trp}^{-} \mathrm{Cb}^{r} \mathrm{Fla}^{-}$ & - & - & Repressed \\
\hline P. putida (arvilla) & $\mathrm{PaW} 340$ & TOL : :Tn401§ & $\mathrm{Tol}^{+} \operatorname{Trp}^{-} \mathrm{Cb}^{r} \mathrm{Str}^{r} \mathrm{Fla}^{+}$ & + & + & ND \\
\hline P. putida & PpS388 & TOL.1 & $\mathrm{Tol}^{+} \mathrm{Trp}^{-} \mathrm{Rif}^{\top} \mathrm{Fla}^{-}$ & - & - & ND \\
\hline P. putida (arvilla) & PaW340 & TOL.1" & $\mathrm{Tol}^{+} \operatorname{Trp}^{-} \operatorname{Str}^{\Gamma} \mathrm{Fla}^{+}$ & + & + & ND \\
\hline P. putida & $\mathrm{AC} 37$ & TOL wild-type & $\mathrm{Tol}^{+} \mathrm{Met}^{-} \mathrm{Fla}^{-}$ & + & + & Constitutive \\
\hline
\end{tabular}

* Abbreviations: $\mathrm{Tol}^{+}$and $\mathrm{Tol}^{-}$denote the ability and inability to metabolize $m$-toluate, respectively; Fla ${ }^{+}$and $\mathrm{Fla}^{-}$denote the presence and absence of flagella, respectively; $\mathrm{Trp}^{-}$, requirement for tryptophan; $\mathrm{Met}^{-}$, requirement for methionine; $\mathrm{Str}^{\mathrm{r}}$, chromosomal resistance to streptomycin; $\mathrm{Rif} \mathrm{f}^{\mathrm{r}}$, chromosomal resistance to rifampicin; $\mathrm{Cb}^{r}$, resistance to carbenicillin determined by transposon $\mathrm{Tn} 401$.

$\dagger$ Indicated by standard spot test for lytic activity of bacteriophages: +, clearing; - , no clearing.

$\ddagger$ Determined by electron microscopy (Bradley, 1980a); ND, not done.

$\S$ Carries transposon Tn401.

1. TOL. 1 is the wild-type plasmid TOL after transfer to strain PpS388. 
receptors (conjugative pili) constitutively (see Meynell et al., 1968), as is the case with TOL and its derivatives when they are in a $\mathrm{PaW}$ background. However, the $P$. putida strain PpS1094(TOL : :Tn401) was not lysed by the phages, indicating repression of the transfer system of the plasmid. In order to determine whether or not the repression was due to the host or the plasmid, we transferred TOL : :Tn401 to PaW340 and found that transconjugants were lysed by the phages, indicating host-controlled repression. Similarly, TOL became repressed in $P$. putida $\mathrm{PpS} 388$ when transferred from $\mathrm{PaW} 1$, and regained its state of derepression when transferred back into a PaW background (PaW340). The lysis of P. putida AC37(TOL) (which has no known connection with P. putida $\mathrm{mt}-2$ ) by phages PR 4 and PRD1 showed that the natural derepression of TOL was not restricted to a $P$. putida $\mathrm{mt}-2$ host.

\section{Transfer frequencies of TOL for liquid and solid media}

Under optimum mating conditions (plate mating), TOL transferred about 1000 -fold better in a PaW background (derepressed) than it did when in its repressed state in P. putida PpS388 (Table 2). In its derepressed state the plasmid transferred between 17-fold and 84-fold better on plates than in broth. No transfer could be detected at the level of sensitivity obtainable for liquid matings when TOL was repressed (Table 2; sensitivity limited by plate mating on transconjugant-selecting plates). Little significance can therefore be attached to these plate/broth transfer frequency ratios.

\section{Characteristics of the TOL pili}

TOL pili formed dense aggregates of filaments; the largest aggregate found is shown in Fig. $1 a$. The basically flexible nature of the pili is clearest on the left of the micrograph. Aggregates were mainly composed of short straight rods with longer pili bending among them. Pili were pointed at one end (Fig. $1 b$, right) and occasionally had what appeared to be a basal structure at the other end (Fig. 1 $c$, left; see Bradley, 1980b). Figure $1(c)$ also suggests that TOL pili are rigid, breaking easily like $\mathrm{N}$ pili (Bradley, 1979), but a broken pilus cannot always be differentiated from two short ones attached end-to-end. Similar broken pili were rare. Pili were determined constitutively (in large numbers; see Bradley, 1980 a) only by derepressed TOL (Table 1). When repressed (in PpS388 and PpS1094 backgrounds), mostly single pili were found at a frequency of about 1 on each square of an electron microscope specimen support grid. TOL pili were 8.5$10 \mathrm{~nm}$ thick depending on the negative staining conditions.

\section{Adsorption of bacteriophage PR4 to TOL pili}

The plasmid-specific, short-tailed phage, PR4, adsorbs to the tips of appropriate conjugative pili (Bradley, 1976, 1979; Bradley \& Cohen, 1977). In an adsorption mixture of TOL pili and PR4 phage virions, about half the aggregates of pili had adsorbed virions, generally only one. Larger aggregates had several phage (Fig. $1 a$, arrowed). Tails were not usually visible.

\section{Table 2. Comparison of TOL transfer frequencies for surface and liquid matings}

\begin{tabular}{|c|c|c|c|c|c|}
\hline \multirow[b]{2}{*}{ Donor strain } & \multirow{2}{*}{$\begin{array}{l}\text { Recipient } \\
\text { strain }\end{array}$} & \multirow{2}{*}{$\begin{array}{l}\text { Selective } \\
\text { medium* }\end{array}$} & \multicolumn{2}{|c|}{$\begin{array}{c}\text { Transfer frequency } \\
\text { (transconjugants per donor } \mathrm{h}^{-1} \text { ) }\end{array}$} & \multirow{2}{*}{$\begin{array}{c}\text { Plate } / \text { broth } \\
\text { transfer frequency } \\
\text { ratio }\end{array}$} \\
\hline & & & Plate & Broth & \\
\hline \multirow[t]{2}{*}{$\mathrm{PaWl}$ (TOL) } & PaW340 & $\mathrm{Mt} \mathrm{Sm}$ & $2 \cdot 1 \times 10^{-1}$ & $1.2 \times 10^{-2}$ & 18 \\
\hline & & & $3 \cdot 2 \times 10^{-1}$ & $2.0 \times 10^{-2}$ & 16 \\
\hline \multirow[t]{2}{*}{$\mathrm{PaW} 226(\mathrm{pWW} 0-226)$} & PaW340 & $\mathrm{Cb} \mathrm{Sm}$ & $4.7 \times 10^{-1}$ & $5.2 \times 10^{-3}$ & 90 \\
\hline & & & $7.7 \times 10^{-1}$ & $1.0 \times 10^{-2}$ & 77 \\
\hline \multirow[t]{2}{*}{ PpS388(TOL. 1) } & PpS388 & Mt Nal & $4 \cdot 1 \times 10^{-4}$ & $<4.0 \times 10^{-6}$ & $>100$ \\
\hline & & & $5 \cdot 1 \times 10^{-5}$ & $<2.4 \times 10^{-6}$ & $>21$ \\
\hline \multirow[t]{2}{*}{ PpS388(TOL: :Tn401) } & PpS388 & $\mathrm{Cb} \mathrm{Nal}$ & $6.3 \times 10^{-5}$ & $<7 \cdot 3 \times 10^{-8}$ & $>860$ \\
\hline & & & $5.4 \times 10^{-5}$ & $<8.5 \times 10^{-8}$ & $>590$ \\
\hline
\end{tabular}

\footnotetext{
* Plasmid selection followed by donor counterselection. Abbreviations: Mt, $m$-toluate medium (see Methods); Sm, streptomycin $\left(800 \mu \mathrm{g} \mathrm{ml}^{-1}\right) ; \mathrm{Cb}$, carbenicillin $\left(2 \mathrm{mg} \mathrm{ml}^{-1}\right): \mathrm{Nal}$, nalidixic acid $\left(200 \mu \mathrm{g} \mathrm{m} \mathrm{m}^{-1}\right)$.

$\dagger$ Expressed to the nearest whole number.
} 

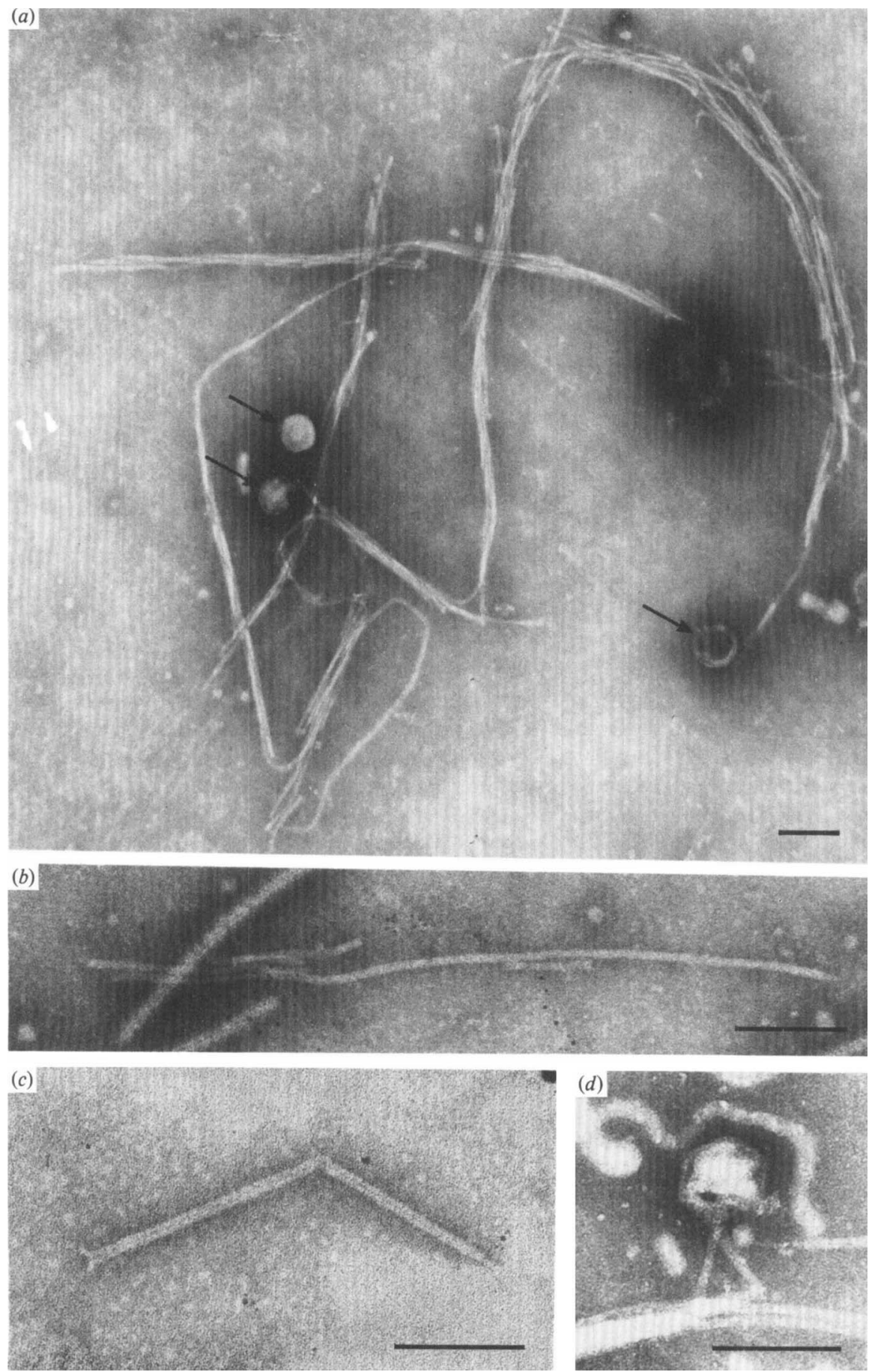

Fig. 1. (a) A large aggregate of TOL pili determined by strain PaW340.3(TOL) grown by a modified 'temporary derepression' method followed by adsorption of phage PR4 (see Methods). Arrows indicate PR4 virions. (b) A long pilus, with its pointed tip on the right from an overnight plate culture of strain PaW226(pWW0-226); the thick rods are flagella. (c) What appears to be a broken pilus from a $6 \mathrm{~h}$ plate culture of strain PpS1094(TOL::Tn401). (d) A PR4 phage virion with two TOL pili attached to it (phage tail not present) from an overnight plate culture of strain PaW340.3(TOL) following PR4 adsorption (see Methods). In each case the bar markers represent $100 \mathrm{~nm}$. 
One example of a virion with two TOL pili attached to it was found (Fig. 1d). While it might be considered that PR4 adsorption to TOL pili as seen in the electron microscope is an artefact, the absence of virions attached to any other part of the pilus (e.g. the sides) is virtually conclusive evidence of specificity (Bradley, 1976). PR4 adsorption to N pili is similar (Bradley, 1979).

\section{PR4-resistant mutants of strain PaW340.3(TOL)}

These spontaneous mutants were prepared in order to determine whether or not the plasmid and/or TOL pili were lost; colonies from double layer agar plates of PaW340.3(TOL) that had been confluently lysed by the phage were grown on nutrient plates previously spread with PR4 suspension. After purification, 72 out of 77 clones were $\mathrm{Tol}^{+}$. We checked $1 \mathrm{Tol}^{-}$and $15 \mathrm{Tol}^{+}$ clones for TOL pili by electron microscopy. This eliminated 7 of the $15 \mathrm{Tol}^{+}$clones : 6 contained numerous PR4 virions (probable PR4 'carrier' strains) and one later proved to be still PR4sensitive. No pili were found for any of the remaining 8 clones, or the Tol- clone. We tested the 8 $\mathrm{Tol}^{+}$clones for transfer to strain PaW340.3 Rif ${ }^{r}$ (resistant to rifampicin) by the cross-streak method (Barth, 1979), but none was detected. Because this method was possibly not sufficiently sensitive to detect low-frequency transfer, we tested two clones using plate mating. They did, in fact, transfer (frequencies $1.6 \times 10^{-4}$ and $3 \cdot 1 \times 10^{-6}$ transconjugants per donor $\mathrm{h}^{-1}$ ). We think it is probable that these clones determined pili, but too few for detection by electron microscopy.

\section{DISCUSSION}

Our spot tests for the lytic activity of phages PR4 and PRD1 are consistent with those of White \& Dunn (1978). However, they did not test the original wild-type $P$. putida $\mathrm{mt}-2$ and so did not obtain complete lysis with any of their strains (the majority of which were $P$. aeruginosa in which TOL is apparently repressed). Our results show that the state of repression of the TOL transfer operon depends upon the host organism. This is reflected both in the ability of phages PR4 and PRD1 to lyse TOL ${ }^{+}$strains, and in the transfer frequencies obtained under optimum mating conditions. Wild-type TOL (pWW0) transfers from PaW1(TOL) at about $2.5 \times 10^{-1}$ transconjugants per donor $\mathrm{h}^{-1}$, which is certainly a derepressed frequency (Bradley et al., 1980). However, we also found that spontaneous PR4-resistant mutants of strain PaW340.3(TOL) contained a repressed version of TOL, presumably similar to TOL. 1 in host strain PpS388 (Table 1).

TOL transferred 17-fold better on a surface than in liquid, and the derived plasmid, pWW0226, transferred 84-fold better. TOL therefore determines a 'surface-preferred' conjugation system (Bradley et al., 1980) as opposed to a 'surface-obligatory' system (plasmids transfer $>1000$-fold better on a surface) or a 'universal' system (transfer is equally good in both environments). However, these different systems have only been demonstrated for $E$. coli $\mathrm{K} 12$ plasmids and it is not known whether or not they are so well defined for Pseudomonas plasmids. A similar situation exists for the three morphological types of conjugative pili identified for $E$. coli K12 (Bradley, 1980a) but not for Pseudomonas. These are: rigid (for 'surface-obligatory' conjugation systems), thick flexible (for 'surface-preferred' or 'universal' systems), and thin flexible (for 'universal' systems). In a preliminary investigation (Bradley, 1981) it was thought possible that TOL determined two pilus types, one rigid and one flexible, but we have only found the latter. However, it has been pointed out that the classification of pili as being flexible or rigid is necessarily somewhat arbitrary and subjective (Bradley, 1980a), relying on their appearance in the electron microscope. A current survey of Pseudomonas conjugative pilus morphology should reveal whether or not such a classification can be reliably applied to pili of this genus. Our observations are consistent with the hypothesis that TOL pili, like other conjugative pili, are involved in plasmid transfer.

We are grateful to Jeannette Fleming and Doris Cohen for valuable technical assistance, and to the Medical Research Council of Canada for financial support (grant no. MA5608). 


\section{REFERENCES}

BARTH, P. T. (1979). Plasmid RP4, with Escherichia col DNA inserted in vitro, mediates chromosomal transfer. Plasmid 2, 130-136.

Benson, S. \& Shapiro, J. (1978). TOL is a broad host range plasmid. Journal of Bacteriology 135, 278-280.

BRaDLEY, D. E. (1976). Adsorption of the R-specific bacteriophage PR4 to pili determined by a drug resistance plasmid of the $\mathrm{W}$ compatibility group. Journal of General Microbiology 95, 181-185.

BRADLEY, D. E. (1979). Morphology of pili determined by the $\mathrm{N}$ incompatibility group plasmid $\mathrm{N} 3$, and interaction with bacteriophages PR4 and IKe. Plasmid 2, 632-636.

Bradley, D. E. (1980a). Morphological and serological relationships of conjugative pili. Plasmid 4, 155-169.

Bradley, D. E. (1980b). Determination of pili by conjugative bacterial drug resistance plasmids of incompatibility groups $\mathrm{B}, \mathrm{C}, \mathrm{H}, \mathrm{J}, \mathrm{K}, \mathrm{M}, \mathrm{V}$, and X. Journal of Bacteriology 141, 828-837.

BradLey, D. E. (1981). Conjugative pili of plasmids in Escherichia coli $\mathrm{K}-12$ and Pseudomonas species. In Molecular Biology, Pathogenicity, and Ecology of Bacterial Plasmids, pp. 217-226. Edited by S. B. Levy, R. C. Clowes \& E. L. Koenig. New York: Plenum Publishing Corporation.

BradLEY, D. E. \& COHEN, D. R. (1977). Adsorption of lipid-containing bacteriophages PR4 and PRDI to pili determined by a P-1 incompatibility group plasmid. Journal of General Microbiology 98, 619623.

Bradley, D. E. \& Rutherford, E. L. (1975). Basic characterization of a bacteriophage specific for plasmids of the $\mathbf{P}, \mathbf{N}$ and $\mathrm{W}$ compatibility groups. Canadian Journal of Microbiology 21, 152-163.

Bradley, D. E., Taylor, D. E. \& Cohen, D. R. (1980). Specification of surface mating systems among conjugative drug resistance plasmids in Escherichia coli K-12. Journal of Bacteriology 143, $1466-1470$.
Downing, R. G., Duggleby, C. J., Villems, R. \& BrodA, P. (1979). An endonuclease cleavage map of the plasmid pWW0-8, a derivative of the TOL plasmid of Pseudomonas putida mt-2. Molecular and General Genetics 168, 97-99.

Fennewald, M. W., Prevatt, W., Meyer, R. \& SHAPIRO, J. (1978). Isolation of IncP-2 plasmid DNA from Pseudomonas aeruginosa. Plasmid 1, 164173.

Meynell, E., Meynell, G. G. \& Datta, N. (1968). Phylogenetic relationships of drug resistance factors and other transmissible bacterial plasmids. Bacteriological Reviews 32, 55-83.

Nakazawa, T. \& Yokota, T. (1973). Conjugal transfer of benzoate pathway genes in Pseudomonas arvilla $\mathrm{mt}$-2. (in Japanese) Japanese Journal of Bacteriology 28, 46.

Olsen, R. H., Siak, J. \& Gray, R. H. (1974). Characterization of PRD1, a plasmid-dependent broad host range DNA bacteriophage. Journal of Virology 14, 689-699.

Rheinwald, J. G., Chakrabarty, A. M. \& GunsaLUS, I. C. (1973). A transmissible plasmid controlling camphor oxidation in Pseudomonas putida. Proceedings of the National Academy of Sciences of the United States of America 70, 825-899.

STANISICH, V. (1974). The properties and host range of male-specific bacteriophages of Pseudomonas aeruginosa. Journal of General Microbiology 84, 332-342.

WhIte, G. P. \& DunN, N. W. (1978). Compatibility and sex-specific phage plating characteristics of the TOL and NAH catabolic plasmids. Genetical Research 32, 207-213.

Williams, P. A. \& Murray, K. (1974). Metabolism of benzoate and the methylbenzoates by Pseudomonas putida (arvilla) $\mathrm{mt}-2$ : evidence for the existence of a TOL plasmid. Journal of Bacteriology 120, 416-423.

Wong, C. L. \& DunN, N. W. (1974). Transmissible plasmid coding for the degradation of benzoate and $m$-toluate in Pseudomonas arvilla $\mathrm{mt}-2$. Genetical Research 23, 227-232. 